\title{
MENINJAU SEJAUH MANA IMPLEMENTASI NILAI PENDIDIKAN KARAKTER MELALUI PENDIDIKAN KEWARGANEGARAAN DI PERGURUAN TINGGI
}

\author{
Shofi Nurul Hikmah \& Dinie Anggraenie Dewi \\ Universitas Pendidikan Indonesia \\ shofinurul512@upi.edu
}

\begin{abstract}
Abstrak
Penelitian ini lebih menekankan kepada sejauh mana capaian pendidikan kewarganegaraan di dalam bentuk implementasi mahasiswa di kehidupan sehari-harinya. Berdasarkan hasil penelitian yang penulis lakukan dengan judul "Meninjau Sejauh Mana Implementasi Nilai Pendidikan Karakter Melalui Pendidikan Kewarganegaraan Di Perguruan Tinggi (Studi Deskriptif Analitik Terhadap Mahasiswa PGSD UPI Cibiru)" dapat diambil kesimpulan sebagai berikut: 1) Dari 18 responden mahasiswa PGSD UPI Cibiru ternyata dalam prakteknya sudah banyak dan mengetahui mengenai kajian materi di dalam mata kuliah pendidikan kewarganegaraan. 2) Namun, dalam bentuk implementasinya dirasa masih sangat kurang dalam kehidupan sehari-harinya. 3) Selain itu, di dapatkan data bahwa para mahasiswa menilai penting sekali pendidikan karakter untuk diberikan pada jenjang yang diampunya. Dengan demikian, orientasi pendidikan kewarganegaraan dalam proses pendidikan karakter bagi mahasiswa ini penting untuk selalu ditanamkan dan diberikan pengarahan. Tujuan ini dapat dicapai jika terjadi bentuk kerja sama antara pemerintah, lembaga pendidikan dan mahasiswa itu sendiri.
\end{abstract}

Kata kunci: pendidikan karakter, mahasiswa, nilai pendidikan kewarganegaraan.

\begin{abstract}
This research emphasizes the extent of the achievements of civic education in the form of student implementation in their daily lives. Based on the results of research conducted by the author with the title "Reviewing the extent to which the implementation of character education values through citizenship education in higher education (Analytical Descriptive Study of PGSD UPI Cibiru students)" can be taken as follows: 1) Out of 18 respondents of PGSD UPI Cibiru students, it turns out that in practice already many and know about material studies in civic education courses. 2) However, in the form of implementation, it is still lacking in daily life. 3) In addition, obtain data that students assess the importance of character education to be given at the level they are attending. Thus, the orientation of civic education in the character education process for students is important to always be instilled and given direction. This goal can be achieved if there is a form of cooperation between the government, educational institutions and the college students. Key Words: character education, college students, the value of civic education.
\end{abstract}

\section{PENDAHULUAN}

Pendidikan adalah salah satu upaya dalam proses belajar untuk tujuan mendewasakan manusia dalam berbagai aspek di dalam kehidupannya (Nurgiansah, 2021c). Menurut Saiful Bahri (2015) Pendidikan merupakan proses pen- galaman yang memiliki pengaruh formatif terhadap cara berpikir individu, merasakan, atau suatu proses yang selalu dilakukan. Pendidikan di Indonesia sendiri terbagi ke dalam beberapa tingkatan atau jenjang, yaitu terdapat Pendidikan formal bagi Sekolah
Dasar (SD), Sekolah Menengah Per- tama (SMP). Sekolah Menengah Atas (SMA) dan Perguruan Tinggi.

Menurut Undang-Undang (UU) Sistem Pendidikan Nasional (Sisdiknas) No. 20 Tahun 2003 Pasal 1 ayat 1 menyebutkan bahwa pendidikan merupakan suatu usaha sadar dan terencana untuk mewujudkan suasana pembelajaran yang dapat mengembangkan potensi peserta didik, keterampilan spiritual, pengendalian diri dan keterampilan-keterampilan yang diperlukan bagi dirinya, masyarakat dan 
negara. Pendidikan adalah salah satu komponen penting di suatu negara yang harus di jalankan dan di dukung penuh prosesnya oleh seluruh elemen atau dengan kata lain seluruh pihak bukan hanya pemerintah saja yang harus peduli terhadap pendidikan (Nurgiansah, 2020b).

Berkaitan dengan pendidikan, di Indonesia sendiri masih banyak tantangan yang harus dilalui dan dihadapi. Saat ini pendidikan di Indonesia masih mengalami kemunduran jika dibandingkan dengan negara-negara asing. Pendidikan di Indonesia masih dianggap sebagai pendidikan yang sesat, hal ini terjadi karena proses pendidikan di Indonesia masih belum bisa sampai kepada tahap hakikat pendidikan yang sebenarnya (Nurgiansah, 2021a).

Pada dasarnya proses pendidikan di Indonesia ini masih selalu melekatkan pendidikan dengan pengetahuanatau biasa disebut juga dengan aspek kognitifnya saja (Nurgiansah, Hendri, et al., 2021). Padahal pendidikan itu meliputi banyak aspek dan pengaruhnya sangat luas. Dewasa ini dampak dari globalisasi mem- berikan efek yang sangat besar bagi keutu- han moral para mahasiswa. Pendidikan kewarganegaraan tidak hanya memberikan pengetahuan tentang kenegaraan saja melainkan selain itu Pendidikan kewarganegaraan juga mempunyai peran penting terhadap aspek moralitasnya. Pendidikan kewarganegaran ini memiliki peran untuk membentuk karakter warga yang baik (Purnomo Aji) (Nurgiansah, Pratama, et al., 2021).

Menurut Debrio M. P (2018) Mahasiswa adalah penggerak dan harapan suatu bangsa untuk mewujudkan tujuan pendidikan nasional yaitu menjadi generasi yang unggul. Keilmuan yang lebih tinggi dibandingkan dengan jenjang lainya, menjadikan mahasiswa memiliki tanggung jawab yang besar sebagai agen pembawa perubahan, khususnya di dunia Pendidikan itu sendiri. Selain harus menjadi contoh yang baik bagi para adik tingkatnya di jenjang SD,SMP dan SMA. Mahasiswa perlu benar-benar mengimplementasikan setiap nilai yang dimuat di dalam kajian pendidikan kewarganegaraan (Nurgiansah, 2020a).

Mengimplementasikan nilai-nilai luhur yang terkandung di dalam pendidikan kewarganegaraan adalah modal utama untuk menciptakan suatu perubahan yang besar. Mahasiswa harus memiliki kekuatan moral dan karakter yang baik di dalam akademik maupun non akademik. Pendidikan karakter di dalam kegiatan akademik yaitu berupa proses belajar dan mengajar yang dalam pelaksanaanya menerapkan sikap-sikap nilai karakter yang sesuai dengan nilai Pancasila. Contohnya seperti kejujuran, kedisiplinan dan religius.

Dengan memberikan pendidikan karakter melalui mata kuliah pendidikan kewarganegaraan kepada mahasiswa adalah sebagai upaya dalam menerapkan nilai- nilai luhur pendidikan kewarganegaraan untuk terciptanya perubahan sejak dini dan sebagai contoh bagi para adik tingkatnya (Nurgiansah, 2020c). Sebagaimana kita ketahui masyarakat Indonesia memiliki paradigma bahwa orang yang memiliki status mahasiswa dan berpendidikan tinggi adalah orang yang memiliki karakter yang baik. Namun, pada saat ini dimana era globalisasi memberikan dampak yang besar. Mahasiswa pun ikutterkena dampak dan dipandang sebelah mata saat ini oleh masyarakat.

Maka dari itu, urgensi karakter mahasiswa dalam akademik harus diperhatikan. Sebab, dengan mengimplementasikan nilai-nilai luhur melalui pendidikan kewarganegaraan pun akan memberikan pengaruh pada kehidupan sosialnya nanti. Penelitian ini 
bertujuan untuk meninjau sejauh mana bentuk implementasi nilai dari ajaran pendidikan kewarganegaraan mahasiswa dan men- jelaskan kaitannya di dalam kegiatan akademik para mahasiswa (Nurgiansah, 2021d).

Pendidikan karakter tidak terlepas kaitannya dengan penanaman nilai-nilai. Menurut Nur Azizah (2015) menyebutkan bahwa penanaman nilai merupakan proses cara pembuatan dan penanaman nilai-nilai luhur yang bertujuan untuk mendidik karakter individunya. Nilai berasal dari kata vale're yang merupakan bahasa latin dan memiliki makna bermanfaat, berdaya, dan sesuatu yang dipandang baik yang menjadi keyakinan dari seseorang ataupun kelompok. Nilai dalam pendidikan kewarga- negaraan memiliki peran yang penting dalam proses akademik.

Di dalam proses akademik yaitu belajar mengajar antara pengajar dengan peserta didiknya harus melibatkan sikap yang terdapat di dalamnilai-nilai Pancasila.

Dewasa ini kita mengetahui bahwa pendidikan kewarga- negaraan memiliki banyak aspek kajian. Salah satunya adalah mengajarkan nilai-nilai luhur Pancasila. Pancasila merupakan pedoman atau dasar negara bagi Indonesia. Sehingga, dalam kehidupan masyarakatnya tidak lepas dari penerapan nilai-nilai kelima sila di dalam Pancasila.

Dengan memiliki nilai maka manusia akan memiliki kehidupan yang terarah dan berprinsip. Pendidikan karakter, nilai dan budi pekerti adalah sesuatu hal yang sama pembahasannya. Hal ini senada dengan penyampaian Kristi Wardani (2014), ia menyebutkan bah- wasanya pendidikan karakter itu merupa- kan nilai budi pekerti yang bersifat afektif. Dimana sifat afektif ini memiliki makna seni, humaniora dan mengembangkan nilai karakter moral.

Menurut Bambang Suryadi (2015) (Nurgiansah, 2021b) makna karakter itu sendiri merupa- kan nilai dasar untuk membangun jiwa seseorang yang baik buruknya itu tergan- tung dari lingkungan yang dihadapi. Pen- didikan karakter pada mulanya disebut oleh Soekarno adalah pembangunan karakter, namun saat ini lebih banyak digunakan dengan penyebutan pendidikan karakter. Di Indonesia saat ini pendidikan karakter mendapatkan perhatian khusus sebab urgensi nya sangat penting sekali bagi peserta didik dan mahasiswa (Andriadi dkk: 2020).

\section{Pendidikan Kewarganegaraan}

Pendidikan kewarganegaraan adalah salah satu ilmu pengetahuan yang wajib dilaksanakan di sekolah-sekolah sampai perguruan tinggi. Untuk di perguruan tinggi itu sendiri pendidikan kewarganegaraan diatur dalam pasal 37 UU No.20 Tahun 2003 mengenai sistem pendidikan nasional. Pendidikan kewarganegaraan ditujukkan untuk memfokuskan para generasi bangsa untuk dapat menjadi warga negara yang baik. Ini sejalan dengan penyampaian (Yunisca Nurmalisa dkk: 2020) yang menyebutkan bahwa pendidikan kewarganegaraan ini bertujuan untuk menjadikan masyarakatnya sadar dan berpikir kritis terhadap hak dan kewajibannya.

Bagi mahasiswa sendiri pendidikan kewarganegaraan ini bertujuan untuk memberikan pemahaman mengenai hak dan kewajiban mahasiswa di dalam lingkungan akademik dan non akademiknya. Selain itu, untuk mengembangkan keterampilan berpikir mahasiswa dalam menghadapi globalisasi yang terus berkem- bang. Tentu saja pengaruh globalisasi ini ha- rus dikritisi oleh para mahasiswa. Menurut (Dr. Winarno: 2020:16) dalam bukunya yang berjudul "paradigma baru pendidikan kewarganegaraan di perguruan tinggi" menjelaskan bahwa banyak sekali perubahan yang telah terjadi mengenai 
pendidikan kewarganegaraan di perguruan tinggi.

Dengan kata lain pendidikan kewarganegaraan sebagai salah satu mata kuliah di perguruan tinggi ini selalu berkembang sesuai dengan perkembangan zaman. Contohnya pada Keputusan Dirjen Dikti No. 43 Tahun 2006 mengenai rambu-rambu mata kuliah pendidikan kewarganegaraan memuat konsep-konsep sebagai berikut: Filsafat Pancasila, Identitas, Hak dan kewajiban, Konstitusi negara, Demokrasi, HAM, Geopolitik dan Geostrategi Indonesia.

Lalu pada tahun 2012 pendidikan kewarganegaraan sebagai mata kuliah di perguruan tinggi semakin diperkuat dengan adanya landasan pasal 35 ayat 3 UU No. 12 Tahun2012, dimana pendidikan kewarganegaraan harus benar-benar memuat aspek religius, Pancasila, kewarganegaraan dan bahasa Indonesia. Dengan demikian dapat disimpulkan adanya mata kuliah pendidikan kewarganegaraan adalah perintah hukum yang kuat yang dilandasi oleh UU dan diberikan kepada mahasiswa di jenjang diploma sertasarjana.

Peran pendidikan kewarganegaraan bagi mahasiswa adalah dengan tujuan agar mahasiswa dapat mengimplementasikan setiap nilai-nilai yang diajarkan dan dilaksanakan dalam bentuk profesinya di masa depan kelak. Dengan begitu pemahaman mengenai pendidikan kewarganega- raan bukan hanya sebatas teori yang disampaikan, namun menjadi hakikat ilmu ke- hidupan yang melekat dan dilaksanakan.

\section{METODE PENELITIAN}

Penelitian ini menggunakan metode studi deskriptif analitik. Dimana menurt (Dr. Priyono: 2016:6) dalam bukunya yang berjudul "Metode Penelitian Kuantitatif" dijelaskan bahwa Analitik adalah salah satu tahapan pendekatan ilmiah yang memper- timbangkan masalah yang dihadapi dan mana yang menjadi masalah utamanya. Selain itu, penelitian ini juga merupakan penelitian kualitatif dan kuantitatif. Dimana metode kualitatif yaitu menurut (Meta Rolitia dkk) adalah mengembangkan penyampaian responden dalam bentuk deskriptif. Pada penelitian ini penulis melakukan survei melalui bentuk kuisioner google form dengan tujuan untuk melihat sejauh mana penerapan nilai-nilai pendidikan kewarganegaraan di implementasikan oleh para mahasiswa. Data yang diperoleh adalah bentuk penelitian kuantitatif karena berisi data responden yang akurat dengan adanya persentase nilai. Penelitian ini lebih menekankan kepada sejauh mana capaian pendidikan kewarganegaraan di dalam bentuk implementasi mahasiswa di kehidupan sehari-harinya.

\section{HASIL PENELITIAN DAN PEMBAHASAN Hasil Penelitian}

Dewasa ini banyak kita temui bahwa karakter para generasi penerus bangsa terkhususnya mahasiswa masih banyak yang mengalami krisis karakter. Pengaruh globalisasi bukan hanya memberi dampak secara ekonomi dan politik saja. Pendidikan pun ikut terseret menjadi objek yang dipengaruhi oleh globalisasi. Senada dengan penjelasan (Eko Priyanto: 2018) menjelaskan bahwa krisis karakter tidak hanya dialami oleh para peserta didik dasar sampai menengah. Namun, di kalangan para mahasiswa pun terkena dampaknya berupa krisiskarakter.

\section{Pembahasan}

Dalam proses membangun karak-ter generasi penerus bangsa adalah dengan melalui pendidikan. Maka, di dalam penelitian ini adalah objek yang kaitannya dengan nilai pendidikan kewarganegaraan. Hanum Almaidah (2018) menyebutkan bahwa pengaruh globalisasi ini sudah 
sangat mengkhawatirkan. Dimana telah terjadi banyak kasus yang menggambarkan degradasi moral di kalangan mahasiswa dan mahasiswi. Ia menemukan bahwa telah terjadi kasus pembuangan seorang bayi yang dilakukan oleh mahasiswi, serta sikap tidak sopan peserta didik kepada gurunya dengan melawan guru menggunakan kekuatan fisik bahkan perbuatannya sampai merugikan guru yang mengakibatkan dirinya kehilangan nyawa.

Dapat kita lihat disini bahwa di kalangan mahasiswa pun nyatanya sudah banyak kasus yang terjadi. Sementara itu, jika dipertanyakan kemana peran pendidikan kewarganegaraan diperguruan tinggi. Jawabannya adalah hanya diri sendiri lah setiap individu bisa me- renungi dan berfikir kembali mengenai hal tersebut. Berkaitan dengan pendidikan karakter. Penulis melakukan kajian survei kepada para mahasiswa dengan memberikan berbagai macam pertanyaan seputar dengan nilai-nilai Pancasila.

Ambiro Puji Asmaroini Tahun 2016 menjelaskan di dalam penelitiannya bahwa kerusakan moral dipengaruhi oleh globalisasi yang menggiring pada hal-hal negatif karena tidak kuatnya kualitas karakter yang dimiliki para peserta didik dan mahasiswa terkhusunya sebagai pelajar di Indonesia. Di dalam pendidikan kewarganegaraan tidak lepas pula pembahasan mengenai Pancasila. Pancasila memiliki pengaruh yang sangat besar bagi pendidikan karakter. Karena, Pancasila merupakan suatu serangkaian nilai-nilai luhur yang dapat menjadi solusi untuk mengatasi kerusakan moral di Indonesia.

Selain itu, menurut Encep Syarief N tahun 2016, pendidikan kewarganegaraan memiliki tujuan untuk mewujudkan mahasiswa menjadi warga negara yang baik yang mampu berkontribusi dalam memajukan negara Indonesia dengan memiliki nilai- nilai Pancasila.

Hal tersebut penulis lakukan agar dapat meninjau sejauh mana para mahasiswa PGSD UPI Cibiru dalam mengimplementasikan nilai-nilai tersebut yang berkaitan dengan kegiatan akademiknya. Maka di dapat hasil berikut ini:

Tabel 1

Data tabel hasil kuisioner dari 18 Mahasiswa PGSD UPI Cibiru

\begin{tabular}{|c|c|}
\hline Bentuk pertanyaan Mengenai & Persentase Ya/Tidak \\
\hline Religius & $50 \%$ \\
\hline Kejujuran & $44,4 \%$ \\
\hline Pengetahuan mengenai PKn & $72,2 \%$ \\
\hline Nilai PKn yang sudah diimplementasikan & $44,4 \%$ \\
\hline Penting tidaknya pendidikan karakter bagi \\
mahasiswa
\end{tabular}


Dapat kita lihat tabel diatas menggam- barkan hasil survei para mahasiswa. Dalam aspek pengetahuan mengenai PKn ternyatabanyak sekali yang mengetahui tentang kajian muatan pendidikan kewarganegaranini. Sementara itu, dalam bentuk implementasinya masih kurang bahkan dari seten- gahnya. Lalu, untuk aspek belum mengimplementasikan nilai pendidikan kewarganegaraan ini ada $55,6 \%$.

Pemahaman mahasiswa terhadap pendidikan kewarganegaraan ini harus benar-benar diimplementasikan di dalam kehidupan sehari-harinya. Sebab, setiap nilai yang terkandung dari pendidikan kewarganegaraan ini lahir dari nilai Pancasila. Menurut (Muchtar, Putri Mahanani, M Imron Rosyad: 2015) setiap sila mengandung nilai yang sangat bermakna dan bermanfaat, yaitu:

1. Pada sila pertama, memberikan pengetahuan dan mengarahkan individu untuk memiliki sikap hormat, toleransi dan kebebasan dalam beribadah.

2. Pada sila kedua, memberikan pemahaman bahwa sumber daya manusia di negara Indonesia harus menggambarkan karakter yang saling mengakui dan menghargai perbedaan.

3. Pada sila ketiga, memberikan pemahaman bahwa negara Indonesia bukan hanya sebuah nama dan tempat yang kita tinggali. Namun, esensinya harus memberikan pengaruh terhadap jiwa para masyarakatnya dan para pelajar Indonesia dalam mencintai tanah air serta menjaga keutuhan.

4. Pada sila keempat, memberikan pemahaman bahwa setiap masalah haruslah diselesaikan dengan cara yang tepat yaitu dengan bermusyawarah dan di dasari dengan hati yang lapang serta ikhlas.

5. Pada sila kelima, memberikan pemahaman bahwa keadilan sosial bukan hanya ditujukkan oleh para pemimpin negara saja. Namun, implementasi nilai sila ini harus diimplementasikan bersama-sama oleh seluruh elemen termasuk mahasiswa.

Dapat disimpulkan bahwa sebetulnya pendidikan kewarganegaraan ini memang sudah tersampaikan secara menyeluruh materi muatanya. Namun, kurangnya aspek kesadaran terhadap nilai-nilai luhur Pancasila yang diberikan oleh mata pelajaran pendidikan kewarganegaraan ini belum sepenuhnya dianggap penting untuk benar-benar dilaksanakan. Menurut Budi Juliardi (2015) dengan lahirnya pendidikan karakter adalah merupakan suatu upaya dalam meningkatkan kesadaran dan implementasian para individu untuk menghidupkan karakter itu sendiri.

Pada prakteknya pendidikan kewarganegaraan ini harus selalu diberikan baik dari jenjang sekolah dasar maupun perguruan tinggi. Jika nilai pendidikan karakter di dalam pendidikan kewarganegaraan ini diimplementasikan maka akanberpengaruh pada masa depan bangsa itu sendiri. Sebagaimana penuturan Anindia Nur Amalia (2020) bahwa pendidikan karakter itu memuat aspek kejujuran, sopan santun, religius, kreativ, kritis, dan menyukai budaya literasi. Dengan demikian, mahasiswa saat ini seharusnya mampu mengembangkan keterampilan nilai kuali- tas diri mereka pribadi.

Pendidikan kewarganegaraan ini bukan sekedar pengetahuan belaka, namun harus benar-benar bisa memberi pengaruh kepada setiap jiwa individunya. Dalam menghadapi revolusi 4.0 pendidikan kewarganegaraan ini sangat penting sekali untuk benar-benar membekali jiwa-jiwa para generasi bangsa. Banyak nilai pendidikan karakter yang perlu ditekankan agar mahasiswa mau untuk dapat 
mengimplementasikannya.

Dalam survei diatas ditanyakan pula mengenai seberapa penting pendidikan karakter bagi para mahasiswa. Mahasiswa pun menjawab sangat penting sekali sebab dengan adanya pendidikan karakter, mahasiswa akan semakin terarahkan dalam menghadapi arus globalisasi. Bahkan, melalui pembelajaran PKn ini mahasiswa harus mencerminkan nilai karakter yang baik untuk terjun ke masyarakat.

Menurut Sukron Mazid dan Suharno Suharno tahun 2019 menjelaskan bahwa peran pendidikan kewarganegaraan ini sangat penting karena memiliki sifat yang strategis dalam membentuk karakter para peserta didik dan mahasiswa. Maka dari itu, para mahasiswa benar-benar harus mem- iliki kesadaran yang penuh dalam mewujudkan Indonesia menjadi negara maju yang memiliki kesejatian karakter sumber daya manusianya. Maka dari itu, maka kita harus menjadikan pendidikan kewarganegaraan ini sebagai misi atau tugas yang harus kita capai bukan hanya sebagai pengetahuan saja.

Hal ini senada dengan penyampaian Hamidah (2019) yang menjelaskan bahwa pendidikan kewarganegaraan ini haruslah dianggap sebagai proses belajar yang dimana mengaitkan proses penerusan pengetahuan, nilai-nilai dan sebagai misi untuk mempersiapkan diri menjadi masyarakat cerdas untuk masa depan. Mahasiswa haruslah memiliki cara berpikir dan bertindak yang dilandasi dengan nilainilai luhur untuk menjadi manusia yang berkualitas dalam memimpin negeri di masa yang akan datang.

\section{KESIMPULAN}

Berdasarkan hasil penelitian yang penulis lakukan dengan judul "Meninjau Se jauh Mana Implementasi Nilai Pendidikan Karakter Melalui Pendidikan Kewarganega- raan Di Perguruan Tinggi (Studi Deskriptif Analitik Terhadap Mahasiswa PGSD UPI Cibiru)" dapat diambil kesimpulan sebagai berikut: 1) dari 18 responden mahasiswa PGSD UPI Cibiru ternyata dalam prakteknya sudah banyak dan mengetahui mengenai kajian materi di dalam mata kuliah pendidikan kewarganegaraan. 2) namun, dalam bentuk implementasinya dirasa masih sangat kurang dalam kehidupan sehari-harinya. 3) selain itu, di dapatkan data bahwa para mahasiswa menilai penting sekali pendidikan karakter untuk diberikan pada jenjang yang diampunya. Dengan demikian, orientasi pendidikan kewarganegaraan dalam proses pendidikan karakter bagi mahasiswa ini penting untuk selalu ditanamkan dan diberikan pengarahan. Tujuan ini dapat dicapai jika terjadi bentuk kerja sama antara pemerintah, lembaga pendidikan dan mahasiswa itu sendiri.

Dalam proses penelitian ini penulis memahami masih banyak sekali kekurangan baik dari segi penulisan, penyampaian materi dan hasil penelitian yang belum sempurna adanya. Maka dari itu, penulis sangat terbuka untuk berbagai pihak yang ingin memberikan kritik dan sarannya.

\section{DAFTAR PUSTAKA}

Amalia Nur Anindia, M Ilham Kharisma. (2020). Pemanfaatan Era Revolusi Industri 4.0 Sebagai Upaya Penunjang Pendidikan Karakter Peserta Didik. Proceeding of the ICECRS, 2-3.

Ambrio, A. P. (2016). Implementasi Nilai-Nilai Pancasila Bagi Siswa Di Era Globalisasi. jurnal pancasila dan kewarganegaraan, 1-6.

Andriadi, Nengah S, Wayan L. (2020). Implementasi Nilai-Nilai Karakter Melalui Mata Pelajaran 
Pendidikan Kewarganegaraan pada SMAN 1 Sawan. Ganesha Civic Education Ejournal, 80-81.

Bambang, S. (2015). Pendidikan Karakter Solusi Mengatasi Krisis Moral Bangsa. uin, 74-76. Budi, J. (2015). Implementasi Pendidikan Karakter Melalui Pendidikan Kewarganegaraan. Jurnal Bhineka Tunggal Ika, 2-4.

Debrio, P. M. (2018). Integritas Akademik Pada Mahasiswa . 2-3.

Eko, P. (2018). Pembelajaran Pendidikan Kewarganegaraan Menerapkan Model Project Citizen Dalam Pembangunan Karakter Mahasiswa. Jurnal Ilmiah Kependidikan, 60-62.

Encep, N. S. (2016). Analisis Konten Dimensi Implementasi Kebijakan Publik pada Konten Kurikulum Pendidikan Kewarganegaraan di Perguruan Tinggi. Jurnal Pendidikan Sains Sosial dan Kemanusiaan, 11-13.

Hamidah. (2019). Implementasi Pendidikan Kewarganegaraan di Perguruan Tinggi.jurnal.iainpadangsidimpuan.ac.id, 27-30.

Hanum, A. (2018). Pembentukan Karakter Mahasiswa Melalui Program Pembentukan Kepribadian dan Kepemimpinan. UIN Malang, 24-25.

Kristi, W. (2014). Proses Penanaman Nilai Budi Pekerti Pada Pembelajaran Kelas Rendah di SD Tamanmuda Ibu Pawiyatan Tamansiswa Yogyakarta. JIPSINDO, 123-126.

Muchtar, Putri Mahanani, M. Imron Rosyadi. (2015). Pemahaman Mahasiswa PGSD Terhadap Implementasi Nilai-Nilai Pancasila. Jurnal Sekolah Dasar, 1-7.

Nur, A. (2015). Penanaman Nilai-Nilai Pendidikan Karakter Dalam Pembelajaran Pendidikan Agama Islam di SMAN 1 Waleri Kendal. UIN Walisongo, 13-26.

Nurgiansah, T. H. (2020a). Fenomena Prostitusi Online Di Kota Yogyakarta Dalam Persfektif Nilai Kemanusiaan Yang Adil Dan Beradab. Jurnal Kewarganegaraan, 17(1), 27-34. https://doi.org/10.24114/jk.v17i1.14208

Nurgiansah, T. H. (2020b). Filsafat Pendidikan. In Banyumas: CV Pena Persada.

Nurgiansah, T. H. (2020c). Pelatihan Penulisan Artikel Ilmiah Bagi Mahasiswa PPKn Universitas PGRI Yogyakarta. JNPM: Jurnal Nasional Pengabdian Masyarakat, 1(1), 16-23.

Nurgiansah, T. H. (2021a). Partisipasi Politik Masyarakat Sleman di Masa Pandemi Covid-19 dalam Konteks Pendidikan Kewarganegaraan. Jurnal Civic Hukum, 6(1), 1-9.

Nurgiansah, T. H. (2021b). Pelatihan Penelitian Tindakan Kelas Bagi Guru Pendidikan Kewarganegaraan Di Sekolah Menengah Atas Se-Kabupaten Bantul. BERNAS: Jurnal Pengabdian Kepada Masyarakat, 2(1), 28-33. https://doi.org/10.31949/jb.v2i1.566

Nurgiansah, T. H. (2021c). Pendidikan Pancasila. In Solok: CV Mitra Cendekia Media.

Nurgiansah, T. H. (2021d). Petuah Pendidikan Kewarganegaraan Dalam Kontestasi Politik. AoEJ: Academy of Education Journal, 12(1), 39-47.

Nurgiansah, T. H., Hendri, \& Khoerudin, C. M. (2021). Role Playing Dalam Pembelajaran Pendidikan Pancasila dan Kewarganegaraan. Jurnal Kewarganegaraan, 18(1), 56-64. https://doi.org/10.24114/jk.v18i1.22597

Nurgiansah, T. H., Pratama, F. F., \& Iman, A. S. (2021). Penelitian Tindakan Kelas Dalam Pendidikan Kewarganegaraan. Jurnal Pendidikan Pancasila Dan Kewarganegaraan, 2(1), 10-23.

Nurmalisa Yunisca, Ana M, Rohman. (2020). Peranan Pembelajaran Pendidikan Kewarganegaraan Dalam Membangun Civic Conscience. Jurnal Bhineka Tunggal Ika, 3942.

Priyono. (2016). Metode Penelitian Kuantitatif. Sidoarjo: Zifatma Publishing.

Purnomo, A. C. (n.d.). Peran PKn dalam Membentuk Karakter Kewarganegaraan Melalui 
Pendekatan Nilai di Perguruan Tinggi. jurnal.uns.ac.id, 1-3.

Rolitia Meta, Yani A, Wahyu E. (n.d.). Nilai Gotong Royong Untuk Memperkuat Solidaritas Dalam Kehidupan Masyarakat Kampung Naga. 5-6.

Saiful, B. (2015). Implementasi Pendidikan Karakter Dalam Mengatasi Moral Di Sekolah. Ta'alum, 1-2.

Sukron Mazid, Suharno Suharno. (2019). Implementasi nilai-nilai multikultural dalam pembelajaran pendidikan kewarganegaraan. Jurnal Pendidikan IPS, 1-7.

Winarno. (2020). Paradigma Baru Pendidikan Kewarganegaraan . Jakarta: Bumi Aksara. 